\title{
The influence of instructional materials on mathematics achievement of senior secondary students in Akamkpa Local Government Area of Cross River State, Nigeria
}

\author{
Bassey $^{14}$, S. W., Ndiyo ${ }^{15}$, N. A. \& Joshua ${ }^{16}$, M. T.
}

\begin{abstract}
Having observed the reckless abandonment of professional codes and ethics of teaching soon after certification, and specifically the subterfuge of the use of instructional materials in lesson delivery, the researchers set out to investigate the state-of-the-art in terms of availability and use of mathematical instructional materials, and the influence of these on students' achievement in the subject. Three instruments, a 20-item Mathematics Teacher Instructional Materials Availability Questionnaire (TIMAQ), a 20-item Mathematics Teacher Instructional Material Use Questionnaire (TIMUQ) and a 30-item Multiple Choice Achievement Test (MCAT) were developed, validated (test-retest reliability coefficients of 0.87 and 0.97 respectively for TIMAQ and TIMUQ, and KR-20 coefficient of 0.89 with mean 40.8, S.D. 11.33) for MCAT. Two hundred (200) students (20 per school comprising 100 male and 100 female) were selected from the ten public secondary schools in Akamkpa Local Government Area by stratified random technique, and two (2) Mathematics teachers per school for the study. Results of the simple percentage and independent t-test analyses revealed the non-availability and non use of instructional materials in Mathematics instruction, as well as significant achievement differences between materials-available and non-available schools on one hand and achievement of students from material-used and non -used schools on the other. Useful recommendations were therefore made based on these findings.
\end{abstract}

Keywords mathematics instructional materials, students' achievement, availability of instructional materials, use of instructional materials

\section{Introduction}

Research and scholarly observation clearly reveal that most teachers engage in extreme verbalism, a degree of verbosity that causes boredom with the concomitant absentmindedness among learners especially in the developing nations. Put differently, a typical secondary school classroom is largely characterized by 'teacher talk' and 'pupil talk', with little or no time for non - verbal communication (Okon, 2005). This view had since been articulated when Amidon and Flanders (1963) averred that:

a visit to a randomly selected classrooms will confirm the fact that the predominant instructional behaviour of the teacher is talking. Indeed, almost 70 percent of classroom instructional time is spent in talk by either the teacher or student.

Consequently, they proposed the monitoring and control of teacher verbalism through Flander's interaction analysis category (FIAC) system.

Mathematics on the other hand, as the study of number and space is heavily symbolic, quantitative and precision - driven. By its nature, Mathematics is spiral and full of both

\footnotetext{
${ }^{14}$ Bassey, Sam William is a lectures at the Department of Curriculum and Instructional Technology, Cross River University of Technology, Akamkpa Campus, Nigeria. Email: basisamwil@yahoo.com

15 Ndiyo, N. A. (Ph.D) lectures at the Department Of Economics, University of Calabar, Nigeria

16 Joshua, M. T. (Ph.D) lectures at the Department of Education Foundations, University of Calabar, Nigeria. Email: monjoshua@yahoo.com
} 
vertical and horizontal integrations, the kind of connectedness that links a lower - order concept with a higher - order concept, such that mastery of the difficult topics is virtually impossible until the related simpler ones have been understood. Since the subject is dreaded like a hydrogen bomb (Denga, 1997), no effort should be spared at reducing mathematics abstractions and adopting instructional strategies aimed at de-mystifying the discipline through its teaching (Bassey 2003). The use of instructional materials in pedagogy has been advocated as the panacea for improving mastery and understanding. According to Ibe \& Bassey (1988), an instructional material is an object of communication that stores and distributes human experiences of knowledge. When effectively used, the materials stimulate students' interest, help retention of factual ideas, aid teaching, improve teacher competence and make learning more meaningful for students. They also enhance visual imagery, stimulate and scintillate learners (Araromi, 1988). Furthermore, instructional materials meet the special need of making the lesson vital, fresh, and intellectually lasting, thus solving problems posed by individual differences in abilities of the learner (Upe, 1996). The significance of instructional materials make them very critical in determining school standards, for institutional accreditation and public valuation. It is a vital school quality variable. Adequate use of school material is known to be associated with instructional effectiveness (Okon, 2005 and Elijah 2000).

Upe (1996) Sought to determine the influence of instructional materials on mathematics achievement of secondary school students in Biase Local Government Area of Cross River State. Four hundred (400) students from five (6) secondary schools were sampled through the stratified random technique, to include 210 females and 190 males. An experimental design was used with the aid of research assistants, where the control group was taught without instructional materials, while the experimental group was taught with instructional materials. The post-test given after two (2) weeks revealed that the use of instructional materials had significant effect on mathematics achievement.

Another researcher, Elijah (2000) sought to investigate the effects of improvised instructional materials on Rivers State Students' performance in Mensuration. Eighty four (84) senior Secondary III students were selected by simple random sampling, and were randomly assigned to the experimental and control groups, such that each group had 21 male and 21 female students. The experimental group was taught using improvised instructional materials, while the control was taught by conventional chalkboard approach. Both groups were given pre and post tests. The result showed that students taught with improvised materials performed significantly better than those with traditional chalkboard drawings and sketches. Gender was not a significant factor based on the analysis.

The gaps identified in the literature reviewed include the absence of empirical information on both availability and use of the mathematics instructional materials - the state-of-the-art of instructional materials in our secondary schools. Most studies focused on what the effects will be if materials are used. Besides, the studies cited above were conducted outside Akamkpa Local Government Area. There is need therefore to obtain empirical information on this vital subject matter of material availability and utilization in Akamkpa Local Government Area of Cross River State, Nigeria. Availability, adequately, selection and use of instructional materials are related to critical issues in teacher professional practice (Okon, 2005 and Melone, 1980). A teacher cannot use materials that are not available, yet availability does not automatically imply effective use. Unless the materials are available, adequate, selected and effectively used, the desired results may not be achieved. 


\section{Statement of the Problem}

Worries about poor students' performance in School Certificate Mathematics are recurrent and even virtually perennial in Nigeria, as each year school certificate (WAEC and NECO) results data present only another tale of woes (see Table 1).

Table I Students' Performance in GCE O - Level Mathematics (1981 - 1991) of Candidates by Grade in Nigeria

\begin{tabular}{llllll} 
Year & Entry & Total 1-6 & Total 7-8 & Total 9 & \% in 1 -6 \\
\hline 1981 & 215315 & 13478 & 51556 & 150281 & 6.26 \\
1982 & 286920 & 12575 & 89495 & 159345 & 44.46 \\
1983 & 341758 & 30399 & 95508 & 125851 & 8.89 \\
1984 & 388346 & 40710 & 100374 & 247262 & 10.48 \\
1985 & 254264 & 52011 & 117487 & 284766 & 11.45 \\
1986 & 523852 & 53414 & 129999 & 340439 & 10.20 \\
1987 & 411258 & 57860 & 112517 & 240881 & 14.07 \\
1988 & 4733116 & 102670 & 132909 & 237737 & 21.69 \\
1989 & 91142 & 7985 & 27342 & 55815 & 8.76 \\
1990 & 195133 & 20614 & 72830 & 101689 & 10.56 \\
1991 & 294079 & 32727 & 155240 & 146112 & 11.13 \\
\hline \multicolumn{5}{r}{ Source: WAEC, Abuja } &
\end{tabular}

Scholars have pointed accusing fingers to different factors as causative agents responsible for the consistently poor students' Mathematics performance. Poor instructional materials is said to be one major cause of this anomaly according to Okon (2005) and Eniayeju (1987). Though so much has been done in teacher preparatory institutions to inculcate the culture of teaching with instructional materials, to acquire improvisation skills, coupled with government effort at on - the - job teacher retraining programmes in the forms of teacher workshops, conferences and vocation courses, the results have hardly improved. This scenario therefore calls for curiosity and raises questions like:

(1) Are there Mathematics Instructional Materials (availability) in our schools?

(2) Are instructional materials actually being used in mathematics instruction?

(3) Do students in schools where these instructional materials are used perform mathematically better than those in other schools?

\section{Purpose of the study, research questions and hypotheses}

The purpose of this study is to verify level of material availability and use as well as the influence of instructional materials on the mathematics achievement of the SS III students in Akamkpa Local Government Area of Cross River State. Specifically, the study should be able to determine:

(1) the level of availability of mathematics instructional materials in the school.

(2) the level to which instructional materials are used in mathematics teaching and learning. 
The influence of instructional materials on mathematics achievement of senior secondary students in Akamkpa Local Government Area of Cross River State, Nigeria Bassey, S. W., Ndiyo, N. A. \& Joshua, M. T.

(3) whether students from materials - available schools perform mathematically better than those from materials - unavailable schools.

(4) whether students from materials-used schools perform mathematically better than those from materials-unused schools.

The following hypotheses were formulated to guide the study:

1. What is the level of availability of mathematics instructional materials in the secondary school?

2. To what extent are the mathematics instructional materials used in daily lesson delivery?

3. There is no significant difference between the mathematics performance of students from materials - available schools and those from materials - unavailable schools.

4. There is no significant difference between the mathematics performance of students from materials - used schools and those from materials - unused schools.

\section{Methodology}

\section{Research Design}

The research design employed in this study is the survey typology, specifically chosen because the researcher is interested in collecting data on an already existing phenomenon, the state of the art of availability and use of instructional materials in secondary school mathematics education in Akamkpa Local Government Area of Cross River State.

\section{Area of the Study}

The study was conducted in secondary schools in Akamkpa Local Government Area of Cross River State, Nigeria. This geographical area is bounded by Biase, Odukpani, Yakurr, Akpabuyo Local Government Areas and the republic of Cameroun. It is blessed with a lot of natural resources, notably timber, precious stones and agricultural products. Akamkpa is indeed the food basket of the State. It is also the home of the Faculty of Education of the multi-campus Cross River University of Technology.

\section{Population and Sample}

The target population comprises all Mathematics teachers and SS III students of public secondary schools in Akamkpa Local Government Area. Twenty SS II students (comprising 10 male and 10 females) of each of the ten (10) secondary schools were selected by stratified random technique from intact classes. The male students were assigned numbers and thirty slips of paper comprising ten (10) valid ones, shuffled and put in a bag for the students to pick from randomly, with replacement. The same was done for female students. This gives a sample size of 200 students. The head of mathematics department and one SS III mathematics teacher of each of the sample schools also completed the questionnaire as the representative teachers. Thus, twenty (20) teachers also formed part of the sample. The sample distribution is shown in Table 2.

Table 2 Sampling Table

\begin{tabular}{|c|c|c|c|c|}
\hline \multirow[b]{2}{*}{ Name of School } & \multicolumn{2}{|c|}{$\begin{array}{l}\text { Number of Students } \\
\text { Respondents }\end{array}$} & \multirow{2}{*}{$\begin{array}{l}\text { Number of } \\
\text { Teacher } \\
\text { respondents }\end{array}$} & \multirow[b]{2}{*}{ Total } \\
\hline & Male & Female & & \\
\hline Comty Sec. school Iko Ekperem & 10 & 10 & 2 & 22 \\
\hline
\end{tabular}




$\begin{array}{llllll}\text { 2. } & \text { Cmty. Secondary school Uyanga } & 10 & 10 & 2 & 22 \\ \text { 3. } & \text { Cmty. Secondary. School. Ojor } & 10 & 10 & 2 & 22 \\ \text { 4. } & \text { Govt. Secondary School Akamkpa } & 10 & 10 & 2 & 22 \\ \text { 5. } & \text { Govt. Day Science School Akamkpa } & 10 & 10 & 2 & 22 \\ \text { 6. } & \text { Comty, Secondary school Mbarakom } & 10 & 10 & 2 & 22 \\ \text { 7. } & \text { Comty. Secondary School Old Netim } & 10 & 10 & 2 & 22 \\ \text { 8. } & \text { Comty. Secondary School Obung } & 10 & 10 & 2 & 22 \\ \text { 9. } & \text { Comty. Secondary school Oban } & 10 & 10 & 2 & 22 \\ \text { 10. } & \text { Secondary School Akin } & 10 & 10 & 2 & 22 \\ & \text { Total } & 100 & 100 & \mathbf{2 0} & \mathbf{2 2 0}\end{array}$

\section{Instrumentation}

Three instruments, the teacher instructional materials availability questionnaire (TIMAQ), the teacher instructional materials use questionnaire (TIMUQ), and a standardized mathematics achievement test (MCSAT) were designed for use by the researcher. TIMAQ was meant for the mathematics teachers while TIMUQ was meant to be completed by the students in the sample. This approach is considered appropriate because students can easily assess use of materials, while teachers are in a better position to report on availability of the instructional materials.

The teacher instructional materials availability questionnaire (TIMAQ) comprises five (5) personal data items and a list of twenty (20) basic Mathematics Instructional materials. Teachers are expected to tick against Highly Available (HA), Available (A), Scarcely Available (SA) and completely unavailable (CU). In the same vein, the TIMUQ comprised the same five (5) personal data items and same set of Twenty (20) basic Mathematics instructional materials for the students respondents to mark the level of use to which each has been put by the teacher. They were to tick against Highly used (HU), Used (U), scarcely used (SU) and Completely Unused (CU). Thus each of the two instruments was a 4 - point Likert - type questionnaire of rating scale format. The achievement test is a 30 - item, 4 - option multiple test (mean 0.4 and average difficulty 0.3 ).

The instruments were independently face - validated by two experts each of Measurement and evaluation and Mathematics Education among academics of the University of Calabar, Nigeria. They were then trial - tested on SS III students and teachers (2006/2007) of two secondary schools in Biase Local Government Area of Cross River State. The instruments were re-administered after two weeks to the same respondents. The result showed satisfactory test - retest reliability coefficient of .87 and 0.92 for the student and teacher instruments respectively. The achievement test lasted for one hour and comprised items in number and numeration (10), algebraic processes (10), Trigonometry (4), Statistics (2) and geometry (4), mean 40.8, reliability (KR-20) 0.89 and Standard Deviation 11.33.

\section{Method of Data Collection}

The instruments were personally administered by the researcher with the aid of a Ph.D student of Research/Statistics, University of Calabar. In each school visited, the researcher obtained permission from the principal (or the vice - principal), and with the consent liased with the head of mathematics department and consequently reach the students. Intact classes were used and the simple random sampling technique employed within the classes. This helped to ensure one hundred percent $(100 \%)$ return rate of the instruments. 


\section{Scoring of data and method of analysis}

The response options highly available (HA), Available (A), Scarcely Available (SA) and Completely unavailable (CU) were coded 3, 2, 1 and 0 respectively with item mean 1.50. Similarly, the response options - Highly used (HU), Used (U) Scarcely Used (SU) and completely unused (CU) were also coded 3,2, 1 and 0 respectively. Consequently, the expected item mean response is 1.5 (average of 3,2,1 and 0). Any response below the mean (1.50) is considered virtually unavailable. The same consideration holds for the measurement of use of instructional material. Any school that has a 50 percent rating on availability or use was considered to have possessed acceptable level of availability or use of instructional materials. That is a rating of 1.5 and above per item in 10 out of 20 items/materials was considered acceptable.

Based on the above criterion, descriptive statistics, frequency counts, simple percentages and mean were used in the analysis of the research questions (1) and (2). For the two hypotheses, the test of significance for two independent group means of achievement scores, where the scores are metric, with normality and random sampling assumed, the independent $t$-test is considered most appropriate and was therefore used in the analysis. 


\section{Results}

Research Question 1 What is the level of availability of mathematics instructional materials in the secondary schools?

Results of the teachers' ratings of availability of mathematics instructional materials in the secondary schools are presented in Table 3.

Table 3 Teachers' rating of Availability of Mathematics Instructional material in Secondary Schools

\begin{tabular}{|c|c|c|c|c|c|c|}
\hline \multirow[b]{2}{*}{$\mathbf{S} / \mathbf{N}$} & \multirow[b]{2}{*}{ Instructional Material } & \multicolumn{2}{|c|}{ Available (A) } & \multicolumn{2}{|c|}{ Not Available (NA) } & \multirow[b]{2}{*}{ Remark } \\
\hline & & Number & Percent & Number & Percent & \\
\hline 1 & Chalk board $(\mathrm{CB})$ protractor & 2 & $(10 \%)$ & 18 & $(90 \%)$ & N.A. \\
\hline 2 & C.B. pair of compasses & 4 & $(20 \%)$ & 16 & $(80 \%)$ & N.A. \\
\hline 3 & C.B. set square & 2 & $(10 \%)$ & 18 & $(90 \%)$ & N.A \\
\hline 4 & C.B. pairs of dividers & 1 & $(5 \%)$ & 19 & $(95 \%)$ & N.A. \\
\hline 5 & Metre rule & 12 & $(60 \%)$ & 8 & $(40 \%)$ & Available \\
\hline 6 & Chalk board & 14 & $(70 \%)$ & 6 & $(30 \%)$ & Available \\
\hline 7 & Duster & 16 & $(80 \%)$ & 4 & $(20 \%)$ & Available \\
\hline 8 & Graph board & 5 & $(25 \%)$ & 15 & $(74 \%)$ & N.A. \\
\hline 9 & Model of Sphere & 7 & $(35 \%)$ & 13 & $(65 \%)$ & N.A. \\
\hline 10 & Mathematical Charts & 7 & $(35 \%)$ & 13 & $(65 \%)$ & N.A. \\
\hline 11 & Model of Cuboid & 6 & $(30 \%)$ & 14 & $(70 \%)$ & N.A. \\
\hline 12 & Model of cube & 6 & $(30 \%)$ & 14 & $(35 \%)$ & N.A. \\
\hline 13 & Model of Cylinder & 7 & $(35 \%)$ & 13 & $(65 \%)$ & N.A. \\
\hline 14 & Model of Pyramid & 4 & $(20 \%)$ & 16 & $(80 \%)$ & N.A. \\
\hline 15 & Model of Prism & 7 & $(35 \%)$ & 13 & $(65 \%)$ & N.A. \\
\hline 16 & Model of Hemisphere & 0 & $(0 \%)$ & 20 & $(100 \%)$ & N.A. \\
\hline 17 & Ludo or die & 0 & $(0 \%)$ & 20 & $(100 \%)$ & N.A. \\
\hline 18 & Four figure tables & 7 & $(35 \%)$ & 13 & $(65 \%)$ & N.A. \\
\hline 19 & Calculators & 6 & $(30 \%)$ & 15 & $(75 \%)$ & N.A. \\
\hline \multirow[t]{3}{*}{20} & Mathematical Set & 5 & $(25 \%)$ & 15 & $(75 \%)$ & N.A. \\
\hline & Mean (x) & 5.90 & $(29.5 \%)$ & 14.1 & $(70.5 \%)$ & \\
\hline & Standard Dev. (s) & 4.25 & & 5.25 & & \\
\hline
\end{tabular}

From the above, the availability of mathematics instructional material is grossly inadequate in our schools, with teacher mean rating of material availability as $29.5 \%$ 
The influence of instructional materials on mathematics achievement of senior secondary students in Akamkpa Local Government Area of Cross River State, Nigeria Bassey, S. W., Ndiyo, N. A. \& Joshua, M. T.

Research Question 2 To what extent are the mathematics instructional material used in daily lesson delivery?

Table 4 shows the students' rating of extent of use of mathematics instructional materials in daily lesson delivery.

Table 4 Number and percentage (in parenthesis) of students rating of extent of use of mathematics instructional materials in secondary schools

Instructional material

1 Chalkboard (CB) Protractor

2 C.B. pair of compasses

3 C.B. set square

4 C.B. pairs of dividers

5 Metre rule

6 Chalk board

7 Duster

8 Graph board

9 Model of Sphere

10 Mathematical Charts

11 Model of Cuboid

12 Model of cube

13 Model of Cylinder

14 Model of Pyramid

15 Model of Prism

16 Model of Hemisphere

17 Ludo or die

18 Four figure tables

19 Calculators

20 Mathematical Set

Mean (x)

*Note: Used (U) or Not Used (NU)

\section{Often used \\ Sometime Used \\ Not used \\ Remarks*}

\begin{tabular}{|c|c|c|c|}
\hline $0(0.0 \%)$ & $12(6.0 \%)$ & $118(94.0 \%)$ & N.U \\
\hline $14(7.0 \%)$ & $70(35.0 \%)$ & $116(58.0 \%)$ & N.U. \\
\hline $0(0.0 \%)$ & $18(9.0 \%)$ & $182(91.0 \%)$ & N.U. \\
\hline $0(0.0 \%)$ & $4(2.0 \%)$ & $196(98.0 \%)$ & N. U. \\
\hline $27(13.5 \%)$ & $148(74.0 \%)$ & $25(12.5 \%)$ & $\mathrm{U}$ \\
\hline $200(100.0 \%)$ & $0(0.0 \%)$ & $0(0.0 \%)$ & $\mathrm{U}$ \\
\hline $159(79.5 \%)$ & $41(20.5 \%)$ & $0 .(0.0 \%)$ & $\mathrm{U}$ \\
\hline $0(0.0 \%)$ & $86(43.0 \%)$ & $114(57.5 \%)$ & N.U. \\
\hline $0(0.0 \%)$ & $47(23.5 \%)$ & $153(76.5 \%)$ & N.U. \\
\hline $0(0.0 \%)$ & $38\left(19.0^{\wedge}\right)$ & $162(81.0 \%)$ & N.U \\
\hline $18(9.0 \%)$ & $43(21.5 \%)$ & $139(69.5 \%)$ & N.U. \\
\hline $12(6.0 \%)$ & $29(14.5 \%)$ & $159(79.5 \%)$ & N.U. \\
\hline $15(7.5 \%)$ & $36(18.0 \%)$ & $149(74.5 \%)$ & N.U. \\
\hline $6(3.0 \%)$ & $32(16.0 \%)$ & $162(81.0 \%)$ & N.U. \\
\hline $0(0.0 \%)$ & $17(8.5 \%)$ & $183(91.5 \%)$ & N.U. \\
\hline $0(0.0 \%)$ & $8(4.0 \%)$ & $192(96.0 \%)$ & N.U. \\
\hline $0(0.0 \%)$ & $0(0.0 \%)$ & $200(100.0 \%)$ & N.U. \\
\hline $26(13.0 \%)$ & $142(71.0 \%)$ & $32(16.0 \%)$ & U. \\
\hline $11(5.5 \%)$ & $52(26.0 \%)$ & $137(68.5 \%)$ & N.U. \\
\hline $14(7.0 \%)$ & $64(32.0 \%)$ & $122(61.0 \%)$ & N.U \\
\hline $25.10(12.5 \%)$ & $44.35(22.17 \%)$ & $130.55(65.28 \%)$ & N.U. \\
\hline & & & \\
\hline
\end{tabular}

From the above table, mathematics instructional materials are hardly used in daily instruction. This is shown by the percentage mean use rating of $12.55 \%$ for often used, $22.17 \%$ for sometimes used and 65.285 for not used. By this, the aggregate index of usability was $34.72 \%$. 
Hypothesis 1

There is no significant difference between the mathematics performance of students from materials-available and materials-unavailable schools

The results of the independent t-test for the statistical difference between the means of the students from materials-available and those from materials-unavailable schools are presented in Table 5.

Table 5: Independent t- test analysis of significance between Mathematics performance of Students from materials - available and material unavailable schools

\begin{tabular}{|c|c|c|c|c|c|c|c|}
\hline Variable & $\mathbf{n}$ & $(\bar{x})$ & Sd & d.f. & $\mathbf{t}_{\text {cal }}$ & t-crit & Decision \\
\hline \multirow[t]{2}{*}{$\begin{array}{l}\text { Performance in materials - } \\
\text { available schools PMAS }\end{array}$} & 40 & 50.2 & 3.5 & & & & \\
\hline & & & & 198 & $5.71^{*}$ & 1.972 & sig \\
\hline $\begin{array}{l}\text { Performance in Materials- } \\
\text { unavailable - schools PMUS }\end{array}$ & 160 & 46.6 & 3.81 & & & & \\
\hline
\end{tabular}

From the above table, there is a significant difference between the mathematics performance of students from material-available schools and those from materials-unavailable schools. This interpretation is based on the fact that the calculated t-value of 5.71 is greater than the critical t-value of 1.972, at 0.95 level of significance. Therefore the null hypothesis is rejected.

Hypothesis 2

There is no significant difference between the mathematics performance of students from material-used and materials-unused schools

In Table 6, the results of the independent t-test for the statistical difference between the means of the students from material-used and materials-unused schools are presented.

Table 6 Independent t-test analysis of significance between the mathematics performance of students from materials-used and material-unused schools

\begin{tabular}{|c|c|c|c|c|c|c|c|}
\hline Variable & $\mathbf{n}$ & $\bar{x}$ & SD & d.f. & $\mathbf{t}_{\mathrm{cal}}$ & t-crit & Decision \\
\hline \multirow[t]{2}{*}{$\begin{array}{l}\text { Performance in materials used } \\
\text { schools (PMUSES) }\end{array}$} & 20 & 52.1 & 2.96 & & & & \\
\hline & & & & 198 & $6.65^{*}$ & 1.972 & sig \\
\hline $\begin{array}{l}\text { Performance in Materials- } \\
\text { unused - schools (PMUNES) }\end{array}$ & 180 & 47.3 & 3.85 & & & & \\
\hline
\end{tabular}

$* \mathrm{P}<0.05$ significant at 0.05 level

From the above table, there is a significant difference between the mathematics performance of students from materials-used and unused schools. This conclusion is reached based on the fact that the calculated $t$-value of 6.65 is greater than the critical t-test value of 1.972 , at 0.05 level of significance. The null hypothesis is therefore rejected and the alternative upheld. 
The influence of instructional materials on mathematics achievement of senior secondary students in Akamkpa Local Government Area of Cross River State, Nigeria Bassey, S. W., Ndiyo, N. A. \& Joshua, M. T.

\section{Discussion}

The analysis of the first research question revealed a near complete absence of mathematics instructional materials in the secondary schools. A closer look at the analysis further reveals that apart from the trivial instructional materials, namely the chalkboard, duster and metre rule all other materials are assessed (teacher rating) as being highly unavailable. On the average, 70.5 percent of the teachers reported in unison the phenomenon of non-availability of mathematics instructional materials. Scarcity of teaching and learning materials is known to be associated with subject matter abstraction (Denga, 1977 and Bassey 2003), subject hatred and teacher incompetence (Ibe-Bassey, 1988). An environment void of instructional material will therefore be characterized by learner withdrawal syndrome, Mathematics phobia, hatred, poor lecture attendance, lateness in passing assignments, and general negative attitude toward mathematics as may be the case in this study where 65.25 of student respondents affirm the non-use of instructional materials. Of course, how can materials be used when they are not available? Like the issue of availability, the analysis showed that only the chalkboard and duster and metre rule and tables are surely used. Other basic mathematics instruments and calculators are scarcely used. Even if the materials were available, non-use of instructional material has far-reaching consequences on students' achievement in any subject (Elijah, 2000). Where materials are not used, learners remain under-achievers.

Insincerity in educational funding in Nigeria (Bassey and Archibong, 2003 and Chukwuma 2001), where only negligible proportion of budgetary allocations to education are ever released both at state and federal levels may have contributed substantially to this poor material situation in schools without equivalent equivocation, effective funding and equipment could improve school quality and students' achievement.

The test of the first hypotheses showed that students in materials - available schools achieve mathematically higher than those from materials unavailable schools. The second hypothesis further confirmed that students in materials - used school achieve mathematically higher than those from materials - unused schools. These two hypothesis corroborate the earlier findings of Amidon and Flanders (1963), that most classroom behaviour is talking. The use of materials reduces verbalism so where materials are not used, verbosity holds sway. Upe (1996) that mathematics students achieve higher when taught with instructional materials than otherwise, and Elijah (2000) that even when ready-made materials are not handy, the use of improvised instructional material in mathematics instruction will yield significantly improved results than when materials are not used. The mystery in the use of instructional materials lies in its attention - captivating capacity, its ability to aid recall, its natural appeal and associated intrinsic motivation. These virtues are quite worthwhile and worthy of pursuit.

\section{Conclusion}

In conclusion therefore, instructional materials constitute a potent factor influencing Secondary mathematics achievement in Akamkpa Local Government Area. The current situation of both non-availability and non-use of the instructional materials in the subject (mathematics) should be tackled by the collaboration of all stake holders in education.

\section{Recommendations}

Based on the findings of this study, it is recommended that:

(1) A certain percentage of school revenue be set aside for the procurement of instructional materials to facilitate instructional delivery and ensure improved students' achievement in mathematics. 
(2) The Secondary School Board should make a law to ensure institutional compliance with the directive on compulsory yearly acquisition of instructional materials, subject to the boards inspection.

(3) The inspectorate division of the Ministry of Education should be energized and mobilized to supervise and monitor utilization of instructional material in mathematics instruction with counsel and sanction for deliberate non - compliance

(4) Teachers should be re - educated on the need for, and method of improvisation in mathematics teaching and learning. Consequently, seminars and workshops should be organized for teachers on this vital subject matter.

(5) The Cross River State Government's initiative in book - writing for our secondary and primary schools is highly commendable. However, the teachers should be motivated and conditioned to follow up and ensure learners' effective utilization of the texts through regular alignments, projects, quizzes and class activities based on these book - materials.

\section{References}

Amidon, E. \& Flanders, N. (1963). The role of the teacher in the classroom. Minneapolis: Paul Amidon and Associates Inc.

Araromi, M. A. (1988). Effects of visual imagery instruction on achievement in languages with particulars reference to French in Nigeria Journal of Curriculum Studies V1(21), 74.

Bassey, S. W. (2003). Skills and techniques in Mathematics laboratory practicals. Umuhia: Hercon publishers Ltd.

Bassey, U. U and Archibong, I. A (2003) funding strategies for education at the Secondary level in Cross River State. Education for Today 3(3), 13-21.

Chukwuma, G. (2001). Funding of Federal Colleges of Education: Implications for quality education. The Nigerian Teacher Today 9(1), 12-18.

Denga, D. I. (1997). Science and Mathematics Education as key to Nigeria's technological boom in the $21^{\text {st }}$ century in Akamkpa Journal of Science and Mathematics Education AJOSEME I (I), 96 - 10.

Elijah, E. U. (2000). The effect of improvised instructional materials in students performance in mensuration in Annual Conference Proceedings of Science Teachers Association of Nigeria (STAN).

Eniayeju, P. A. (1987). A diagnosis of the O-level science students' performance: the Kano State Case study. Nigeria Educational forum 10(2), 301 - 208.

Ibe - Bassey, G. S. (1988). Fundamentals of educational technology. Uyo: Dorand publishers.

Melone, P. (1980). Successful teaching. Daily Stars: March 19th.

Okon, A. E. P. (2005). Effects of inadequacy of instructional materials in the teaching of social studies in junior secondary schools in Abak LGA of Akwa Ibom State, Nigeria. An unpublished B.Ed. Project of University of Calabar.

Upe, A. U. (1996). Instructional materials and students mathematics performance in Biase LGA. An unpbulsihed NCE Project of the National Teachers Institute (NTI). 
The influence of instructional materials on mathematics achievement of senior secondary students in Akamkpa Local Government Area of Cross River State, Nigeria Bassey, S. W., Ndiyo, N. A. \& Joshua, M. T. 